\title{
Comentário
}

\section{Crianças e adolescentes em situações de risco no Brasil}

Muito já se falou sobre crianças e adolescentes em situações de risco. A palavra "risco" deriva-se do latim resecare"cortar". ${ }^{1}$ Pode-se, então, dizer que essas situações de risco cortam as crianças e os adolescentes, ou seja, cortam seus direitos e suas potencialidades. Mantêm, no entanto, intacto o círculo vicioso da miséria - crianças e adolescentes que vivem na pobreza e têm seus direitos fundamentais negados tendem a tornar-se adultos que pouco poderão passar a seus filhos, além da herança da miséria e da marginalização.

A pobreza e toda a infinidade de problemas a ela associados dificultam a vida de milhões de pessoas ao redor do mundo, tendo, porém, em crianças e adolescentes suas vítimas preferenciais. As pessoas com idade inferior a 18 anos representam um número desproporcionalmente grande entre os mais pobres e marginalizados. Segundo estudos recentes da Organização das Nações Unidas, ${ }^{2} 40 \%$ das crianças e dos adolescentes dos países menos desenvolvidos tentam sobreviver com menos de um dólar ao dia. Eles não só representam uma parcela muito significativa da população mais pobre do mundo, como também são acometidos pela pobreza em um período crítico de suas vidas, o que lhes compromete o desenvolvimento e lhes provoca efeitos danosos de longa duração, tanto físicos quanto psicossociais.

A pobreza costuma acompanhar-se do desrespeito aos direitos humanos fundamentais, não sendo diferente em relação às crianças e aos adolescentes. Pode-se lembrar, como exemplo, das 130 milhões de crianças fora da escola no mundo ou das milhares de outras que morrem diariamente de causas perfeitamente evitáveis, caso lhes fosse garantido o acesso a uma boa alimentação, água potável, esgoto e serviços de saúde. ${ }^{2}$ Interessante notar, porém, que, embora seja comum que tais desrespeitos acompanhem as situações de pobreza, esta não explica totalmente a ocorrência de abuso e discriminação contra a criança - outros fatores estão, nesse contexto, envolvidos e devem ser estudados para que mudanças verdadeiras possam acontecer.

O Brasil, como um país em desenvolvimento, infelizmente possui um grande número de crianças e de adolescentes em diversas situações de risco. Por questões de clareza, podese falar em grupos de crianças com necessidade de medidas de proteção especiais, embora, muitas vezes, uma mesma criança viva mais de uma dessas situações. Há, assim, as crianças trabalhadoras, as exploradas sexualmente (comercialmente ou não), as deficientes, as envolvidas com a rua, as discriminadas pela identidade étnica ou religiosa ou por gênero, as em conflito com a lei e as institucionalizadas.

Como exemplo, pode-se citar o grande contingente de crianças trabalhadoras - para cada dez crianças brasileiras, uma trabalha. ${ }^{3}$ São 866 mil crianças de sete a 14 anos alistadas como trabalhadoras no país, sendo que esse número inclui apenas as crianças que trabalham nas piores modalidades de trabalho infantil, segundo a Organização Internacional do Trabalho, como o trabalho escravo ou forçado, a venda e o tráfico de crianças, as atividades ilícitas (como a produção e o tráfico de drogas), os trabalhos perigosos à saúde ou à segurança de crianças (como trabalhos em carvoarias, no corte de cana, na fabricação de tijolos etc.), entre outros. ${ }^{3}$ Estão excluídas dessa estatística, por exemplo, as prostitutas mirins e as milhares de crianças, geralmente meninas, que fazem trabalhos domésticos no Brasil. Empregar crianças no trabalho doméstico, muitas vezes em idade bastante precoce, é uma prática muito comum e bem aceita no país, embora possa ser bastante prejudicial às crianças e aos adolescentes - a carga de trabalhos é, muitas vezes, pesada, e muitos trabalhadores não conseguem freqüentar a escola. Por acontecer em ambiente privado - de certo modo, escondido -, é difícil normatizar e vigiar o trabalho doméstico.

Prosseguindo com os números, há aproximadamente 100.000 crianças de sete a 18 anos vivendo nas ruas do país. ${ }^{2}$ Cerca de um milhão de crianças e adolescentes vivem institucionalizados, distantes do convívio familiar por diferentes motivos e submetidos, freqüentemente, às diversas formas de violência e privação. ${ }^{4}$ Em pesquisa sobre a saúde mental de crianças e adolescentes criados em instituições sérias e respeitadas, verificou-se que eles apresentavam risco para transtornos psiquiátricos cerca de seis vezes maior em relação a quem vivia com suas famílias. ${ }^{4}$ Assim, pode-se supor que a saúde mental de crianças e adolescentes que vivem em outras instituições menos adequadas esteja sob risco ainda maior.

Os exemplos citados são suficientes para reafirmar, mais uma vez, a urgência de mudanças. Tais mudanças devem passar pelo estudo detalhado e multidimensional das situações que envolvem a infância e a adolescência, tanto brasileiras quanto mundiais. Não deve-se seguir considerando essas crianças e adolescentes apenas vítimas e passivos beneficiários de medidas que se proponham a ajudá-los. Tal postura, além de ter-se mostrado pouco eficiente ao longo do tempo, tende a ser estigmatizadora, mantendo tais crianças e adolescentes como perpétuos marginalizados e perdedores. Tem-se de estar atento para a força de resistência e adaptação dessas crian- 
ças e adolescentes - não são apenas vítimas, mas também sobreviventes de um cotidiano muito adverso que se assemelha muito a uma verdadeira guerra. Crianças e adolescentes estão em grave risco, mas a própria palavra "risco" guarda em seu significado a noção de ganho. Diz o Aurélio: "risco é a situação em que há probabilidades mais ou menos previsí- veis de perda ou ganho". Deve-se utilizar esse tema com olhos nos preciosos ganhos que se podem colher.

Susane Rocha de Abreu

Escola Paulista de Medicina da Universidade Federal de São Paulo, SP, Brasil

\section{Referências}

1. Novo Aurélio: dicionário da Língua Portuguesa, século XXI. Versão 3.0. São Paulo: Nova Fronteira.

2. CIDA (Canadian International Development Agency). Action Plan on Child Protection. June, 2001. http//www.acdi-cida.gc.ca

3. Cipola A. O trabalho infantil. São Paulo: Publifolha; 2001.

4. Abreu SR. Transtornos psiquiátricos em crianças e adolescentes criados em instituições. São Paulo; 2000. 